\title{
Peran Manajemen Keuangan Pada Usaha Mikro Kecil Dan Menengah (UMKM) Batik Dalam Memajukan Sektor Kewirausahaan
}

\author{
Nailariza Umami \\ Pendidikan Ekonomi, STKIP PGRI Tulungagung \\ Email: nailariza@stkippgritulungagung.ac.id
}

Received: 7 Januari, 2019; Accepted: 20 Maret, 2019; Published: 25 Juni, 2019

\begin{abstract}
Abstrak
Salah satu langkah yang dilakukan oleh Indonesia berdasarkan rencana strategis pemerintah untuk menghadapi MEA adalah dengan penguatan sektor kewirausahaan. Tetapi pada kenyataannya masih rendahnya pengetahuan pelaku usaha batik tentang pentingnya manajemen keuangan demi keberlangsungan usaha yang dirintisnya untuk bisa ikut serta dalam perdagangan bebas antar negara di kawasan Asia Tenggara menjadi permasalahan yang harus diselesaikan, agar Indonesia memiliki kesempatan yang baik untuk menunjukkan kualitas dan kuantitas produk serta Sumber Daya Manusia (SDM) kepada negara-negara lain dengan terbuka. Dalam UMKM keterampilan manajemen sangat diperlukan, utamanya Manajemen Keuangan. Manajemen keuangan adalah semua aktivitas perusahaan yang berhubungan dengan usaha-usaha mendapatkan dana perusahaan dengan biaya vang murah serta usaha untuk menggunakan dan mengalokasikan dana tersebut secara efisien (Sutrisno :3, 2009). Untuk itu tujuan dalam penelitian ini adalah untuk mengetahui peran daripada manajemen keuangan pada Usaha Mikro Kecil dan Menengah (UMKM) Batik dalam memajukan sektor kewirausahaan. Penelitian ini termasuk penelitian deskriptif kuantitatif yang dilaksanakan di Usaha Mikro Kecil dan Menengah (UMKM) Batik Satrio Manah Desa Bangoan Kecamatan Kedungwaru Kabupaten Tulungagung, dikatakan demikian karena dalam penelitian ini hanya menggambarkan manajemen keuangan pada Usaha Mikro Kecil dan Menengah (UMKM) Batik Satrio Manah. Responen dalam penelitian ini adalah semua karyawan Batik Satrio Manah yang berjumlah 50 orang. Teknik dan instrument pengumpulan data dalam penelitian ini adalah wawancara, angket, dan dokumentasi. Analisa data dilakukan dengan mengolah skor hasil pengamatan pada laporan keuangan dan angket. Adapun hasil yang peneliti peroleh adalah pengelolaan manajemen keuangan pada Usaha Mikro Kecil dan Menengah (UMKM) Batik Satrio Manah belum memenuhi standart pengelolaan keuangan yang baik, dan masih perlu adanya penyempurnaan sesuai standar pengelolaan yang tepat.

kata Kunci: Manajemen Keuangan, Usaha Mikro Kecil dan Menengah (UMKM), Sektor Kewirausahaan
\end{abstract}

\footnotetext{
Abstract

One of the steps taken by Indonesia based on the government's strategic plan to deal with MEA is to strengthen the Micro, Small and Medium Enterprises (MSME) sector. But in reality the knowledge of batik entrepreneurs is still low
} 
about the importance of financial management for the continuity of the business he initiated to be able to participate in free trade between countries in the Southeast Asian region to be a problem that must be resolved, so that Indonesia has a good opportunity to show product quality and quantity and Human Resources (HR) to other countries openly. In MSME management skills are very necessary, especially Financial Management. Financial management is all company activities related to businesses obtaining company funds with low costs and efforts to use and allocate these funds efficiently (Sutrisno: 3, 2009). For this reason, the purpose of this study was to determine the role of financial management in Batik Micro, Small and Medium Enterprises (UMKM) in filling the MEA (Asean Economic Community. This research included quantitative descriptive research carried out in Batik Satrio Micro Small and Medium Enterprises (UMKM) Manah Bangoan Village, Kedungwaru Subdistrict, Tulungagung District, is said to be because in this study only describes financial management in the Satrio Manah Batik Micro Small and Medium Enterprises (UMKM) .The respondents in this study were all 50 Satrio Manah Batik employees Data in this study are interviews, questionnaires, and documentation Data analysis is done by processing the scores of observations on financial statements and questionnaires. The results obtained by the researchers are management of financial management in Micro, Small and Medium Enterprises (UMKM) Batik Satrio Manah has not met the standard keu management good dreams, and there still needs to be improvement in accordance with financial management standards.

KeyWords: Entrepreneurship Sector, Financial Management, Micro, Small and Medium Enterprises (UMKM),

\section{PENDAHULUAN}

Perekonomian Indonesia selalu menjadi topik pembicaraan hangat elemen masyarakat. Khususnya kondisi UKM Indonesia sangatlah cukup memprihatinkan, dengan tingkat usaha aktif kurang dari $10 \%$. Kesejahteraan selalu menjadi tolak ukur perekonomian. Home industri merupakan salah satu sektor yang memiliki peran penting dalam pembangunan perekonomian Indonesia. Pengelolaan yang tepat pada sektor ini dapat meningkatkan jumlah ekspor produk lokal, peningkatan jumlah peyerapan tenaga kerja serta dapat meningkatkan pendapatan petani lokal.

Diperkirakan angka pengangguran di Kabupaten Tulungagung terus mengalami peningkatan. Hal tersebut menunjukkan jumlah pencari kerja lebih tinggi dari jumlah lapangan kerja yang tersedia. Besaran jumlah penduduk telah menimbulkan berbagai ekses dalam kehidupan masyarakat. Salah satunya berkaitan dengan ketersediaan lapangan kerja. Kuantitas jumlah penduduk yang tinggi tidak diiringi dengan pertambahan lapangan kerja. Masyarakat mengalami kesulitan dalam menemukan lapangan pekerjaan. Ditengarai berbagai bidang pekerjaan yang 
tersedia tidak mampu menampung besarnya jumlah tenaga kerja. Semakin hari jumlah pencari kerja semakin meningkat yang tidak diimbangi dengan kesediaan lapangan kerja. Terbatasnya lapangan kerja menimbulkan persaingan yang begitu ketat dalam seleksi pekerjaan. Sebagian 2 kecil dari tenagakerja dengan kemampuan berkualitas yang diterima sedangkan anggota masyarakat yang lain tidak mendapat pekerjaan bahkan menjadi pengangguran. Jika memperoleh pekerjaan itupun kurang layak atau tidak sesuai dengan kemampuan yang dimiliki. Karena minimnya lapangan kerja yang tersedia menggugah keinginan sebagian pencari kerja di wilayah Tulungagung untuk berwirausaha. Melihat tantangan dan peluang di sekitar kemudian menciptakan lapangan kerja sesuai dengan kemampuan individu. Berwirausaha dipandang sebagai salah satu cara untuk mengatasi minimnya lapangan kerja dan mengurangi angka pengangguran. Motivasi kuat untuk bekerja, inovasi tiada henti dan modal yang dapat disesuai dengan kondisi keuangan menjadikan wirausaha menjadi salah satu profesi unggulan di masa sekarang.

Kewirausahaan (entrepreneurhip) merupakan persoalan penting di dalam perekonomian suatu bangsa yang sedang berkembang. Kemajuan atau kemunduran ekonomi suatu bangsa sangat ditentukan oleh keberadaan dan peranan dari kelompok wirausahawan. Proses perubahan ekonomi tergantung pada orang yang menyebabkan timbulnya perubahan tersebut yakni sang "entrepreneur". 3 kreativitas dan jiwa inovator yang tinggi. Seseoarang yang memiliki kreativitas dan jiwa inovator tentu berpikir untuk mencari atau menciptakan peluang yang baru agar lebih baik dari sebelumnya (Zimmerer, 1996:10).

Kewirausahaan (entrepreneur) telah lama menjadi perhatian penting dalam mengembangkan pertumbuhan sosio ekonomi suatu daerah. Tidak dapat dipungkiri bahwa kewirausahaan dapat membantu menyediakan begitu banyak kesempatan kerja, berbagai kebutuhan konsumen, jasa pelayanan, serta menumbuhkan kesejahteraan dan tingkat kompetisi suatu negara. Selain itu, seiring dengan berkembangnya arus globalisasi, kewirausahaan juga semakin menjadi perhatian penting dalam menghadapi tantangan globalisasi yaitu kompetisi ekonomi global dalam hal kreativitas dan inovasi. Hal ini disebabkan karena organisasi-organisasi 
yang terampil dalam berinovasi, sukses menghasilkan ide-ide baru,mendapatkan keunggulan bersaing dan tidak tertinggal di pasar dunia yang terus berubah dengan cepat. Jadi, kewirausahaan merupakan suatu kemampuan dalam menciptakan nilai tambah di pasar melalui proses sumber daya dengan cara-cara baru dan berbeda (Suryana, 2006). Bagi Indonesia, keberadaan MEA menjadi babak awal untuk mengembangkan berbagai kualitas perekonomian di kawasan Asia Tenggara dalam perkembangan pasar bebas di akhir 2015. MEA menjadi dua sisi mata uang bagi Indonesia, satu sisi menjadi kesempatan yang baik untuk menunjukkan kualitas dan kuantitas produk serta sumber daya manusia (SDM) Indonesia kepada negaranegara lain dengan terbuka, tetapi pada sisi yang lain dapat menjadi boomerang untuk Indonesia apabila Indonesia tidak dapat memanfaatkannya dengan baik.

MEA akan menjadi kesempatan yang baik karena hambatan perdagangan akan cenderung berkurang bahkan menjadi tidak ada. Hal tersebut akan berdampak pada peningkatan eskpor yang pada akhirnya akan meningkatkan Gross Domestik Produk (GDP) Indonesia. Dengan adanya perdagangan bebas, kita matnpu meningkatkan ekspor akan tetapi kita juga harus waspada akan resiko kompetisi (competition risk) yang muncul dengan banyaknya barang impor yang akan mengalir dalam jumlah banyak ke Indonesia, hal tersebut dapat mengancam industri lokal dalam bersaing dengan produk-produk luar negeri yang jauh lebih berkualitas. Hal ini pada akhirnya akan meningkatkan defisit neraca perdagangan bagi Indonesia sendiri, Terwujudnya sistem pasar bebas ini berarti Indonesia harus siap untuk menghadapi persaingan antar negara anggota. Dalam hal ini, tidak hanya pemerintah, tetapi juga masyarakat harus ikut berperan dalam upaya memenangkan persaingan MEA. Peran pemerintah dalam membentuk regulasi dan perundangundangan tentang masalah investasi dan kompetisi usaha harus diperkuat. Kebijakan yang diambil pemerintah akan jadi penentu kemenangan, atau kekalahan Indonesia dalam era kompetisi MEA, di lain pihak, pemerintah juga harus mernfasilitasi masyarakat dalam mendorong pertumbuhan kualitas barang dan jasa. Pemerintah juga harus menyadari bahwa tanpa peran rnasyarakat, terutama pelaku bisnis, Indonesia akan sulit untuk bersaing dengan negara-negara anggota lainnya. Apalagi, negara-negara tetangga Indonesia merupakan pemain besar di bidang 
ekonomi global, seperti Malaysia dan Singapura. Dalam upaya menghadapi pasar bebas ASEAN Pemerintah menerbitkan Instruksi Presiden (Inpres) Nomor 1 Tahun 2011 tentang Pelaksanaan Komitmen Cetak Biru MEA. Dalam cetak biru MEA, terdapat 12 sektor yang menjadi prioritas yaitu tujuh sektor barang yakni industri agro, otomotif, elektronik, perikanan, industri berbasis karet, industri berbasis kayu, dan tekstil, sisanya berasal dari lima sektor jasa yakni transportasi, udara, kesehatan, pariwisata, logistik, dan teknologi informasi. Sektor-sektor tersebut pada era MEA akan terimplementasi dalarn bentuk pembebasan arus barang, jasa, investasi, dan tenaga kerja. Salah satu langkah yang dilakukan oleh Indonesia berdasaran rencana strategis pemerintah untuk menghadapi MEA adalah dengan penguatan sektor Usaha Mikro Kecil Menengah (UMKM).

Sementara itu, di Kabupaten Tulungagung sendiri, jumlah Usaha Mikro Kecil Menengah (UMKM) jumIahnya banyak. Data yang dilaporkan mencapai sekitar 400, yang akan terus dikembangkan baik tentang manajemen, keuangan, dan pemasaran yang terus didorong melalui Dinas Perekonomian dan Pariwisata (Disperpar) Kabupaten Tulungagung, dan berdasarkan observasi serta wawancara yang peneliti lakukan kepada Dinas Perekonomian dan Pariwisata (Disperpar) bahwa banyak upaya yang dilakukan untuk menghadapi MEA, diantaranya dengan melakukan pembinaan terhadap pelaku usaha. Banyak pelaku usaha yang terdapat di Kabupaten Tulungagung, diantaranya pelaku usaha krupuk rambak, konveksi, batik, dan lain sebagainya. Dan salah satu yang maju di Kabupaten Tulungagung adalah sentra industri batik khususnya Batik Satrio Manah. Batik Tenun Satrio Manah adalah salah satu jenis batik di Indonesia yang memiliki keunikan tersendiri. Begitu pula yang penelitian lakukan kepada UMKM Batik Satrio Manah Desa Bangoan Rt.03 Rw.01 Kecamatan Kedungwaru Kabupaten Tulungagung yang bertahan menekuni tradisi nenek moyang sebagai pengrajin batik. Dalam perkembangan jaman Batik Satrio Manah semakin langka, tetapi Batik Satrio Manah tetap bertahan menekuni usahanya. Menurut Kurniawan (Jurnal Ni Wayan Duti Ariani: 103, 2013): Berbagai permasalahan mikro dapat menghambat perkembangan UMKM terutama dalam mengoptimalkan peluang yang ada. Dapat diidentifikasikan bahwa permasalahan yang sering terjadi pada UMKM yaitu 
kurangnya permodalan, kesulitan dalam pemasaran, persaingan usaha ketat, kesulitan bahan baku, kurang teknis produksi dan keahlian, keterampilan manajerial kurang, kurang keterampilan manajemen khususnya keuangan. Dalam UMKM keterampilan manajemen sangat diperlukan, utamanya Manajemen Keuangan. Manajemen Keuangan merupakan salah satu bagian utama dari ilmu manajemen. Dalam perusahaan manajemen keuangan berhubungan dengan pengambilan keputusan-keputusan keuangan (Mohamad Muslich: 1, 2003). Adapun permasalahan yang ada pada Batik Satrio Manah Desa Bangoan Kecamatan Kedungwaru Kabupaten Tulungagung adalah pengelola manajemen keuangan belum profesional dan pengelolaan manajemen keuangan yang diterapkan tidak menggunakan laporan bulanan hanya menggunakan laporan harian serta penghitungan laba tidak menggunakan laporan keuangan setiap bulan tetapi hanya memperkirakan keuntungan berdasarkan omzet (hasil penjualan) setiap hari. Berdasarkan penelitian terdahulu modal, biaya, harga jual berpengaruh positif dan signifikan terhadap laba usaha mikro dan modal, biaya, serta harga jual secara simultan berpengaruh signifikan terhadap laba pada usaha mikro. Oleh karena begitu banyak yang harus diperhatikan maka pengusaha industri kccil (UMKM) sulit untuk melakukan pengelolaan manajemen keuangan secara lebih efektif.

\section{METODE PENELITIAN}

Penelitian yang ini termasuk penelitian deskriptif kuantitatif. Dikatakan demikian karena dalam penelitian ini diperlukan data penelitian berupa angka angka yang didapat oleh peneliti melalui wawancara dan dokumen-dokumen yang telah diberikan oleh pemilik usaha. Populasi yang dalam penelitian ini adalah seluruh karyawan pada Usaha Mikro Kecil dan Menengah (UMKM) Satrio Manah yang bcrjumlah 50 orang. Sementara itu sampel penelitian yang diambil oleh peneliti adalah sernua karyawan UMKM Batik Satrio Manah yang berjumlah 50 orang. Menurut Arikunto, (2006:170) "Apabila populasi penelitian berjumlah kurang dari 100 maka sampel yang diambil adalah semuanya, namun apabila populasi penelitian berjumlah lebih dari 100 maka sampel dapat diambil antara 10$15 \%$ atau $20-25 \% "$. 
Jenis data yang peneliti gunakan adalah data kualitatif dan data kuantitatif. Dimana data kualitatif berisi, sejarah usaha, struktur organisasi, hasil kuesioner mengenai pengaruh manajemen keuangan, dan data-data lain yang menunjang penelitian. Sedangkan data kuantitatif dalam penelitian ini adalah data keuangan serta data hasil kuesioner yang sudah diangkakan. Dalam Teknik Pengumpulan Data, metode yang dilakukan adalah penelitian lapangan (Field research) yaitu mengkumpulkan data dengan wawancara, dan dokumentasi dengan melihat catatan-catatan penting Usaha Mikro Kecil (UMKN) Batik Satrio Manah yang digunakan sebagai bahan untuk melengkapi data-data penelitian.

Instrumen dalam penelitian ini adalah dengan menggunakan tiga cara yaitu wawancara, kuesioner, dan dokumentasi. Dalam teknik Analisis Data peneliti menggunakan teknik kuantitatif dengan bantuan statistik SPSS. Hipotesis yang digunakan oleh peneliti diuji dengan menggunakan teknik analisis regresi linier sederhana dan uji hipotesis (uji t). Analisis regresi linier sederhana digunakan oleh peneliti dalam penelitian ini yaitu untuk mengetahui bagaimana variabel independen mempengaruhi variabel dependen. Sedangkan uji hipotesis (uji t) sendiri untuk mengetahui signifikan atau tidaknya pengaruh antara variabel $\mathrm{X}$ dan variabel Y.

\section{HASIL PENELITIAN DAN PEMBAHASAN}

Meskipun namanya usaha mikro kecil dan rnenengah tapi bukan berarti jenis usaha tersebut tidak membutuhkan manajemen keuangan. Manajemen keuangan merupakan hal yang mutlak untuk dilakukan oleh setiap pengusaha lintas skala bisnis. Mulai dari skala kecil, menengah sampai dengan skala besar pun wajib metakukan manajernen keuangan untuk usahanya. Karena hal itu menjadi salah satu langkah awal yang. cukup menentukan kesuksesan para pelaku bisnis. Suatu usaha atau organisasi bisnis tentu memerlukan manajemen yang baik dan sesuai standart juga memenuhi kode etik yang berlaku. Hal-hal yang menyangkut peraturan dari usaha ini dikarenakan organisasi bisnis membutuhkan manajemen, manajemen inilah yang menjadi pondasi bagi sebuah usaha. Dimana manajemen adalah pilar tertinggi bagi sebuah usaha. Usaha yang baik tentulah usaha yang memiliki 
manajemen yang baik pula. Contohnya, Manajemen Keungan dalam sebuah usaha. Karena jika sebuah usaha tidak memiliki manajemen yang baik hal ini mempengaruhi keberlangsungan perkembangan sebuah usaha. Jika sebuah usaha dapat mengemukakan dan mempraktikkan manajemen sesuai kode etik yang baik diharapkan usaha tersebut dapat bertahan disaat persaingan yang semakin ketat di era Masyarakat Ekonomi Asean (MEA).

Manajemen keuangan adalah kegiatan manajemen berdasarkan fungsinya yang pada intinya berusaha untuk memastikan bahwa kegiatan bisnis yang dilakukan mampu mencapai tujuannya secara ekonomis, yaitu diukur berdasarkan profit, tugas manajemen keuangan, diantaranya merencanakan darimana pembiayaan bisnis diperoleh. dan dengan cara bagaimana modal yang telah diperoleh dialokasikan secara tepat dalam kegiatan bisnis yang dijalankan. Termasuk ke dalam kegiatan manajemen keuangan adalah bagaimana agar dapat dipastikan hasil alokasi modal yang dipergunakan untuk penjualan produk dapat selalu dapat melebihi dari segala biaya yang telah dikeluarkan, sebagai sebuah indikator pencapaian profit perusahaan.

Manajemen Keuangan bertujuan memaksimalkan nilai dari perusahaan. tujuan utama dari suatu perusahaan adalah untuk meningkatkan kemakmuran para pemegang saham atau pemilik (Sutrisno :4, 2009). Dalam melaksanakan manajemen keuangan dibutuhkan seorang manajer keuangan yang harus menjalankan perannya dengan baik guna mencapai tujuan sutau usaha atau organisasi. Manajer keuangan memiliki beberapa tugas, antara lain :

a. Memperolehan dana/aset dengan biaya sesuai budget perusahaan.

b. Menggunakan clana secara efektif dan efisien

c. Membuat laporan keuangan

Sementara Analisis Data Hasil Penelitian dan Pembahasan dalam penelitian ini Untuk mengetahui pengaruh pengelolaan Manajemen Keuangan pada Usaha Mikro kecil dan Menengah (UMKM) Batik Sekar Ayu peneliti menyebarkan angket kepada 50 orang karyawan Batik Satrio Manah. 
Tabel 1. Kisi-Kisi Soal Angket

\begin{tabular}{llll}
\hline No & Variabel & Indikator & Jumlah Butir Pertanyaan \\
\hline 1 & Manajemen & 1. Pengambilan & A17, A20 \\
& Keuangan (X) & Keutusan & \\
& (Sutrisno 2009) & 2. Perencanaan & A7,A8,A15 \\
& & 3. Pengelolaan & A3,A5,A6,A9,A10,A11, \\
& & 4. Pengendalian & A12,A13, A14, A16 \\
& & 5. Pegelolaan Usaha & A1,A3,A4 \\
\hline \multirow{2}{*}{ Usaha Mikro Kecil } & 1. Kekeluargaan & B5,B10,B13 \\
& dan Menengah & 2. Pertumbuhan & B2,B3,B6,B11,B14 \\
& (UMKM) (Y) (Pasal & kemandirian & \\
& 2 UU No. 20 Tahun & 3. Kebersamaan & B1,B7,B12 \\
& 2008) & 4. Pengembangan Usaha & B15,B16,B17,B18,B19, \\
& & Berbasis Daerah & B20 \\
& & 5. Peningkatan Daya & B4,B8,B9 \\
& & Saing & \\
\hline
\end{tabular}

Hasil pengujian hipotesis yang telah dilakukan oleh peneliti dengan rnengunakan analisis regresi linier sederhana menghasilkan persamaan $Y^{\prime}=6,242$ + 0,903X. Maka peneliti mengambil kesimpulan bahwa setiap kenaikan Pengkelolaan Manajemen Keuangan sebesar 1, maka Usaha Mikro, kecil dan menengah juga meningkat sebesar 0.903. Dari analisis uji hipotesis (uji t) diperoleh hasil terhitung, $>\mathrm{t}$ tabel $(10,733>-2,048)$ dan signifikansi $<0,05(0,0000.05)$ maka Ho ditolak. Maka Ha diterima. Jadi, dapat disimpulkan bahwa Pengelolaan Manajemen Keuangan berpengaruh terhadap Usaha Mikro, Kecil dan Menengah (UMKM). Hal ini didukung dengan hasil penelitian Batara Bernard Simanjuntak, 2005 dengan judul pengaruh kinerja keuangan pada industri menengah. Dalam penelitian tersebut, peneliti menjelaskan bahwa pengaruh kinerja keuangan terhadap harga saham pada industri menengah. Hal itu dibuktikan pada uji hipotesis yang dilakukan dengan metode uji $\mathrm{F}$ (uji secara serentak) hasilnya nilai $\mathrm{F}$ rasio $>\mathrm{F}$ label $(8,444>5,13)$. Artinya terdapat hubungan yang signifikan antara seluruh koefisien regresi variabel independen, yaitu ROE, ROS, MVA dan EVA dengan variabel independen yanu harga saham pada tingkat kepercayaan 95\%. Dan penelitian Diana Hasyim, 2013 dengan judul Kualitas Manajemen Keuangan Pada Usaha Mikro Kecil dan Menengah (UMKM). Dalam penelitian tersebut 
Karakteristik pelaku UMKM sebagian besar (90,9\%) berjenis kelamin dan dari segi usia hcrusia 30 - 45 (54,5\%) dan 46-60 (30,9\%). Kemudian dari tinukat pendidikan sebagian besar (89\%) lulus perguruan tinggi tersebut berpengaruh pada kualitas manajenien yang diterapkan di masing-masing UMKM.

\section{KESIMPULAN}

Dari hasil penelitian ini dapat disimpulkan bahwa pengelolaan manajemen keuangan berpengaruh terhadap Usaha Mikro Kecil dan Menengah (UMKM). Hal ini dapat dilihat dari hasil analisis pengujian hipotesis yang disebutkan di atas. Berdasarkan hasil analisis terhadap data yang telah dikumpulkan maka dapat di tarik kesimpulan bahwa ada pengaruh antara manajemen keuangan dengan Usaha Mikro Kecil dan Menengah (UMKM). Hal ini dapat dilihat dari analisis uji hipotesis (uji t) diperoleh hasil $t$ hitung $>\mathrm{t}$ tabel $(10,733>-2,048)$ dan signifikansi $<0,05(0,000<0,05)$, maka Ho ditolak. Maka Ha diterima Jadi, dapat disimpulkan bahwa Pengelolaan Manajemen Keuangan berpengaruh terhadap Usaha Mikro, kecil dan menengah.

Manajemen keuangan terhadap Usaha Mikro Kecil dan Menengah (UMKM) memiliki pengaruh yang besar. Hal ini dapat dilihat dari hasil analisis regresi linier sederhana menghasilkan persamaan $\mathrm{Y}^{\prime}=6,242+0,903 \mathrm{X}$, yang berarti bahwa setiap kenaikan Pengelolaan Manajemen Keuangan sebesar 1, maka Usaha Mikro Kecil dan Menengah juga meningkat sebesar 0,903.

\section{DAFTAR RUJUKAN}

http://nichonotes.blozspoLco.id/2015/02/manajemen-keuangcm-financemanagement.html diakses tanggal 28 Maret 2016.

Lukas.(1999). Manajemen Keuangan. Yogyakarta : CV Andi Offset

Muslich Mohammad. (2003). Manajemen Keuangan Modern. Jakarta: PT Bumi Aksara

Sjahrial Dermawan. (2007). Manajemen Keuangan Lanjutan.Jakarta. M itra Wacana Media

Sugiono, Arief. (2009). Manajemen Keuangan untuk Praktisi. Jakarta. Grasindo. 
Umami. Peran Manajemen Keuangan Pada Usaha Mikro Kecil dan Menengah (UMKM)...

Tampubolon Manahan. (2005). Manajemen Keuangan. Bogor: Ghalia Indonesia.

Undang-Undang Republik Indonesia Nomor 20 Tahun 2008 tentang Usaha Mikro, Kecil dan Menengah 